NBSIR 78-1427

\title{
Impact of the New Copyright Law on Interlibrary Loan in a Research Library
}

Elsie Cerutti, Interlibrary Loan Librarian Jane C. Tucker, Serials Librarian

Library Division

National Bureau of Standards

Washington, D.C. 20234

January 26, 1978

Prepared for

Library Division

National Bureau of Standards U.S. Department of Commerce

Washington, D.C. 20234 



\section{IMPACT OF THE NEW COPYRIGHT}

LAW ON INTERLIBRARY LOAN IN A

RESEARCH LIBRARY

Elsie Cerutti, Interlibrary Loan Librarian

Jane C. Tucker, Serials Librarian

Library Division

National Bureau of Standards

Washington, D.C. 20234

January 26, 1978

Prepared for

Library Division

National Bureau of Standards

U.S. Department of Commerce

Washington, D.C. 20234

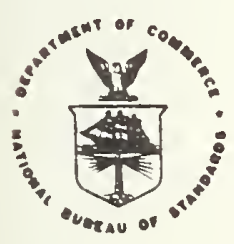

U.S. DEPARTMENT OF COMMERCE, Juanita M. Kreps, Secretary

Dr. Sidney Harman, Under Secrotary

Jordan J. Baruch, Assistant Secretary for Science and Technology

NATIONAL BUREAU OF STANDARDS, Ernest Ambler, Acting Director 



\title{
IMPACT OF THE NEW COPYRIGHT LAW \\ ON INTERLIBRARY LOAN IN A \\ RESEARCH LIBRARY
}

\author{
by \\ Elsie Cerutti \\ Interlibrary Loan Librarian
}

National Bureau of Standards Library

Washington, D.C.

and

Jane C. Tucker

Serials Librarian

National Bureau of Standards Library Washington, D.C. 



\section{ABSTRACT}

A study of interlibrary loan borrowing at the National Bureau of Standards Library in 1976 was made, to forecast the impact of the new copyright law on the Library budget. The study indicates that the majority of journals are requested only once, and that a number of foreign journals are requested. An analysis of subscription cost compared to interlibrary loan cost suggests criteria for management decisions on subscription, as well as testing the fairness of the conTu guidelines in their economic impact on libraries. 

A feature of the 1976 General Revision of Copyright Law (PL94-553) of great interest to librarians is Section 108 (g), an attempt to define more precisely the concept of fair use in interlibrary loan. At the request of the House Judiciary Committee, the National Commission on New Technological Uses of Copyrighted Works (CONTU) developed guidelines, included in the Conference Report, to make the concept of "fair use" in interlibrary photocopy activities more explicit.

The guidelines say that interlibrary loan is considered to be a substitute for a subscription if:

"(a) with respect to any given periodical (as opposed to any given issue of a periodical), [it] filled requests of a library or archives (a "requesting entity") within any calendar year for a total of six or more copies of an article or articles published in such periodical within five years prior to the date of the request. These guidelines specifically shall not apply, directly or indirectly, to any request of a requesting entity for a copy or copies of an article or articles published in any issue of a periodical, the publication date of which is more than five years prior to the date when the request is made. These guidelines do not define the meaning, with respect to such a request, of'...such aggregate 
quantities as to substitute for a subscription to

[such periodical].'" 1

In order to determine the impact of the guidelines on the budget of the National Bureau of Standards Library, we undertook a study of the interlibrary loan requests for 1976, to identify those titles which the library had borrowed frequently enough to exceed the recommended limits for fair use.

\section{THE LIBRARY}

The National Bureau of Standards (NBS) is the laboratory for physical measurements and standards for engineering, manufacturing and commerce in the United States. The projects of the Bureau include research in energy conservation, fire prevention, consumer product safety, properties of materials and computer technology. The Bureau headquarters is housed in 27 buildings on a 233 hectare site in Gaithersburg, Md. There are approximately 2600 staff members, about 1000 of whom are physicists, chemists and engineers. More than forty percent of the professional staff have doctoral degrees. The staff is organized into four Institutes, which are subdivided into divisions and sections. The support staff of the Bureau includes the office of the Associate Director for Information Programs, of which the library is a division.

The main library satisfies part of the information needs of the staff with a collection of 45,000 monographs and 4500 periodical titles, of which approximately 2130 are current journal subscriptions. In addition to the 
main library there are information centers and section collections, limited in scope and independent of the library's control. If an information request cannot be met by materials in the library, other information centers or division collections, then a library staff member requests the item or a photocopy from another information organization. Thus, the main library handles all interlibrary loan requests.

\section{PROCEDURE FOR DATA COLLECTION}

Normally, interlibrary loan request slips from the year in progress are selectively interfiled with older requests, including slips 30-40 years old. A slip is kept only if it provides some unique information to indicate a borrowing institution for future requests. However, for the year 1976 , all of the loan requests were saved in a separate file for this study.

Several problems of definition naturally arose in selecting periodicals from a combined serial-monograph file. Annual reviews were excluded from the requests examined. Technical report series of various institutions were included unless they were cataloged by the Library of Congress as monographic series. In those cases where we were not sure whether the original journal or a translation was wanted, we combined them as one title for courting. The greatest problem arose in counting requests filled tirough the Library of Congress (LC) because NBS Library may borrow journals from LC 
rather than receive photocopies. Items borrowed were counted as single requests, unless the number of citations wanted was given by the user.

We sorted the titles into mutually exclusive groups described by two criteria, number of requests per title and whether the request was for pre-1971 issues, issues of a later date, or both. Of 1180 titles for which 2217 requests were made, 734 requests (about 33 percent) were for pre-1971 issues. Interestingly, 776 titles (about 66 percent) were single requests (see Figure 1). Time constraints made it impossible to verify all 1180 titles, but we checked for changes of title whenever 3 or more requests were made for the same title. For issues published after 1970 no title was shifted to the category of 5 or more requests by title variations. The titles identified for possible subscription, i.e., 6 or more requests for issues published after 1970, were further analyzed as to number of requests per person and division affiliation of the requester.

\section{ANALYSIS}

We found 28 titles with post-1970 issues requested 6 or more times ( 2 percent of the total number of titles) which comprised 260 requests ( $12 \%$ of the total requests). The Library or one of the NBS sections does have subscriptions to 8 of these titles, covering 75 requests. They are analyzed in Table 1. Interlibrary loans were requested for issues of 
these titles because of missing issues or insufficient holdings.

The remaining twenty titles, covering 185 requests ( $8 \%$ of total requests) include both American and foreign copyrighted materials. The American copyrights are listed in Table 2, in order by subscription cost, and the foreign journals in Table 3 , in the same order. The new copyright law presently applies only to works with American copyright, but new international copyright agreements may extend the same guidelines to foreign copyrights.

The journals identified for purchase using the guidelines range in price from $\$ 5.94$ to $\$ 289.80$, with a mean price of $\$ 43.92$; however, the median price is only $\$ 15.00$. This difference indicates the great variability in subscription costs. At the average subscription cost of these journals, if an interlibrary loan costs $\$ 10^{2}, 4$ or 5 requests would justify purchase. Almost half of the journals could be purchased for less than the cost of borrowing them once on interlibrary loan, but the cost of interlibrary borrowing would have to go up to $\$ 25$ to justify purchase of the most expensive journal even at the rate of use shown.

As librarians know, the cost of holding a journal includes more than the subscription price; it also includes processing costs, which vary with the number of issues 
received, the reliability of the publisher (claiming costs), the binding decisions made and storage. Adding in these costs would raise the point at which purchase becomes more economical than borrowing slightly above the level specified in the guidelines, at an interlibrary loan service cost of $\$ 10$ per request.

We next examined the group of journals for which 5 requests were made in 1976, for issues published after 1970. These titles are shown in Table 4 (American imprints) and Table 5 (foreign imprints).

In this group of journals, the mean price of an American imprint is $\$ 47.75$, slightly higher than the mean of the group to be purchased under the guidelines, and the median price is $\$ 20$, slightly higher than the median in the other group. The range of subscription prices is less, from $\$ 8.00$ to $\$ 152$. All but 3 of the journals are worth purchasing at an interlibrary borrowing cost of $\$ 10$. Using the criterion of borrowing cost vs. subscription cost, two of the foreign journals also ought to be purchased. The additional holdings costs discussed above would of course change the breakeven point between interlibrary loan cost and holdings cost.

\section{CONCLUSIONS}

The CONTU guidelines were accepted as "a workable and fair interpretation"3 of the provisions of subsection 108 (g) (2): the Register of Copyright is to make a study in five 
years to see if the guidelines do "balance the interests of the parties."4 Authors, publishers, and libraries all have economic interests in copyright laws, although this is not explicitly stated in the guidelines. No reason is given for the choice of five requests as the suggested limit of fair use; however, it is interesting to note that a 1968 study of borrowing vs. ownership costs identified an average breakeven point of 6 uses of issues published within the past 10 years. 5

It is clear that for a particular journal title, the guidelines are a very rough measure of the point at which interlibrary loan is a true economic substitute for purchase. The economic breakeven point is strongly dependent on the cost of borrowing on interlibrary loan (see Figure 2). Therefore, any developments in interlibrary loan processing which significantly change the service cost should be considered in adjusting the guidelines in future.

Further, this study makes clear that the guidelines should be used cautiously in an economic sense, however rigidly they may be interpreted legally. The true cost of holding journals is quite variable, and many would be more economically purchased than borrowed. The first decision to be made when a request is received is whether or not to purchase the title. Of course, if the request is for a three-year old issue of a popular magazine, purchase may 
not be a feasible option.

This points up an assumption in the guidelines which we were unable to test, because of the way in which interlibrary loan data have been kept. The assumption, looking at 5 years of a journal in making subscription vs. borrowing judgments, is that the same journals will be used from year to year. It is not very economical to purchase a journal for the next 5 years if it was needed this year and will not be needed again. We plan to examine our interlibrary loan records at the end of 1977, to see if the same journal titles are as frequently requested in 1977 as in 1976. A demand for different titles will strongly support the need for a clearinghouse to supply copies of journal articles.

\section{ACKNOWLEDGMENTS}

We would like to thank Joanne DuChez for helping to analyze questionable titles as monographs or serials, Joan Owens for help in filing, and Nadine white for patiently retyping drafts. 
REFERENCES

1. U.S. Congress, House of Representatives. General Revision of the Copyright Law, Title 17 of the United States Code. Conference Report, 94 th Congress, 2nd session. (House of Representatives Report 94-1733) pp. 72-73.

2. Unpublished study on interlibrary loan cost done in 1975 by Elizabeth J. Yeates, former Chief, Library Division, National Bureau of Standards.

3. General Revision of the Copyright Law, Conference Report, p. 73 .

4. General Revision of the Copyright Law, Conference Report, p. 9 .

5. Library cost models: owning versus borrowing serial publications. Gordon Williams, et al. Washington, National Science Founation, 1968. 
776 Distribution of Requests among Titles

188

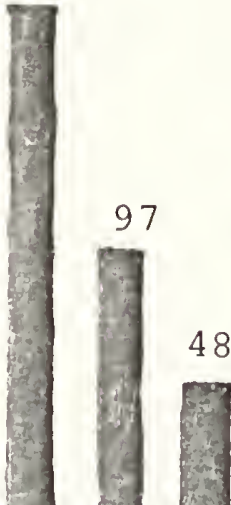

$18 \quad 16$

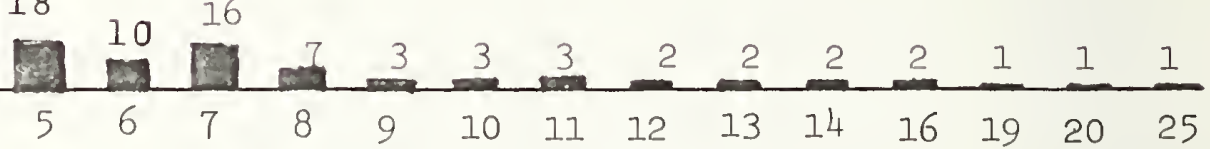

TOTAL NUMBER OF REQUESTS/TITLE 


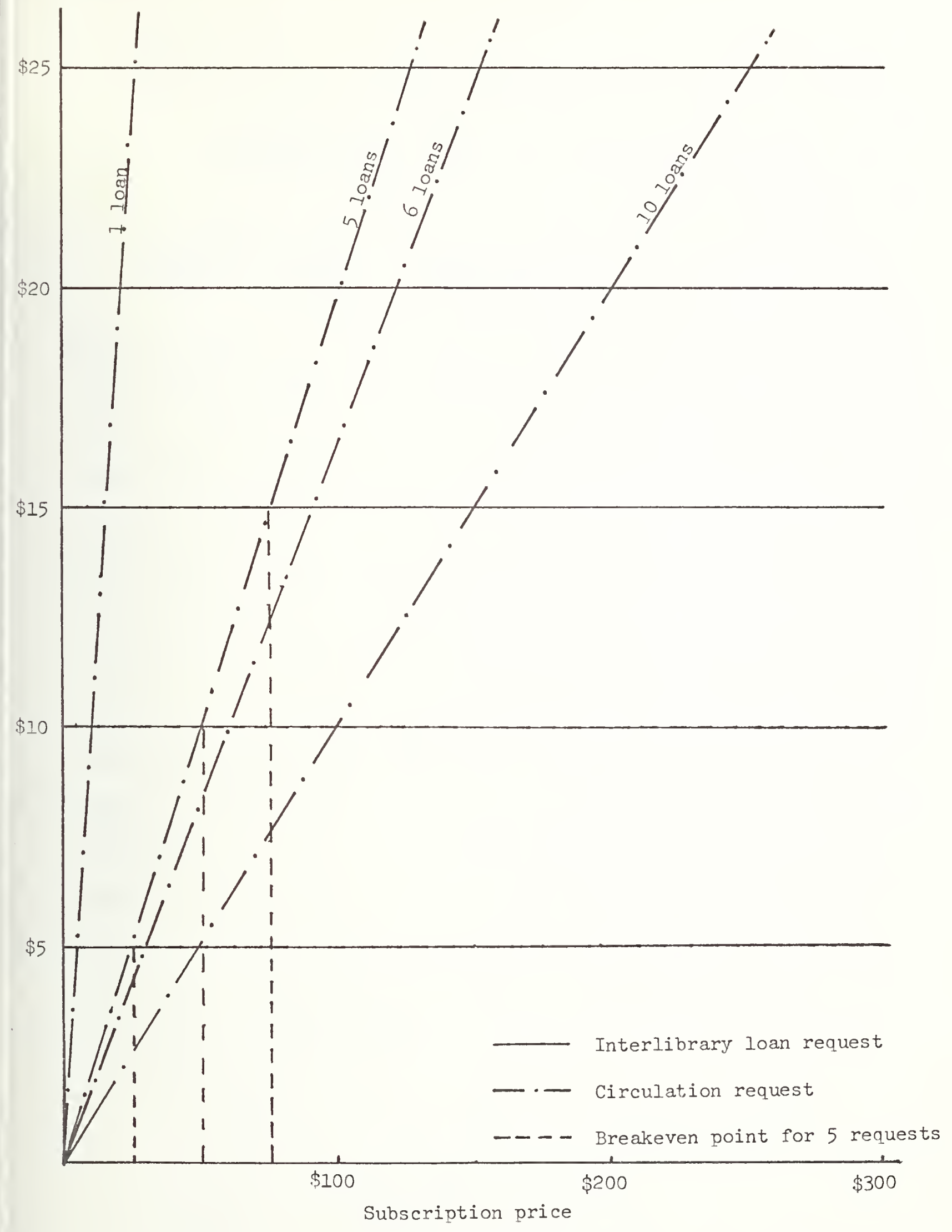

FIGIJE 2

Comparative Cost of Filling a Request by Subscription or Interlibrary Loan 
TABLE 1 .

Journals Held by Library or Other Divisions

\section{Title}

Soviet journal of non-

destructive testing

Combustion, explosion

$$
\text { and shock waves }
$$

Clinical orthopaedics \&

$$
\text { related research }
$$

Journal of bone and joint

$$
\text { surgery (Am. ed.) }
$$

Consumers' research

$$
\text { magazine }
$$

Journal of applied

$$
\text { probability }
$$

Journal of bone and joint

$$
\text { surgery (Brit. ed.) }
$$

organic mass spectrometry
Holdings

$1976+$

20

10

$1975+$

19

17

No. of Requests

Total 1971+ 
TABLE 2 .

Journals With American Copyright

Requested More Than Five Times

\section{No. of Requests}

\section{Total $1971+$}

1. American Home

2. Popular Mechanics

3. Popular Science

4. Good Housekeeping

5. Changing Times

6. Health Laboratory Science

7. Air Conditioning, Heating

\& Refrigeration News

8. Nation

9. Journal of Sports Medicine

10. Physician and sports

Medicine

11. Applied Ergonomics

12. Bulletin of Environmental

Contamination \& Toxicology

$\begin{array}{ll}7 & 6 \\ 7 & 7\end{array}$

14

6

$\cdot 14$

11

11

6

7

6

6

7

6

Subscription

$\underline{\text { Price }}$

$\$ 5.94$

7.00

7.94

7.97

9.00

9.00

15.00

19.50

20.00

14

24.00

$\begin{array}{ll}7 & 7\end{array}$

$6 \quad 59.80$

$7 \quad 6$

8

8

96.00

13. Contributions to Mineralogy

and Petrology

TOTALS
$\$ 570.95$
289.80

$$
\begin{aligned}
& \text { Mean price }=\$ 43.92 \\
& \text { Median price }=\$ 15.00
\end{aligned}
$$


TABLE 3.

Foreign Journals Requested More Than Five Times

$\frac{\text { No. of Requests }}{\underline{\text { Total }} \quad \underline{1971+}} \quad \frac{\text { Subscription }}{\text { Price }}$

1. Which (British Consumers

$\begin{array}{llll}\text { Assn.) } & 13 & 13 & 7.00 * *\end{array}$

2. Izvestiia VUz

Tsvetnaia metallurgiia

16

15

21.00

3. Fortschritte der

Mineralogie. Beihefte

8

8

$58.21 *$

4. CIRP Annalen

10

6

82.15

5. British Medical Journal

7

7

85.00

6. Neues Jahrbuch für

Mineralogie. Monatshefte

11

10

142.60

7. Societe Chimique de

France. Bulletin

TOTALS

$\frac{16}{81} \quad \frac{16}{75} \quad \frac{198.00}{\$ 593.96}$

*Price of the Beihefte (Supplement) varies. Journal and Supplement $\$ 58.21$.

**Using $=\$ 2.80$ as an exchange rate; quoted price $\$ 2.50$. Mean price $=\$ 84.85$

Median price $=\$ 82.15$ 


\section{TABLE 4 .}

Journals with American Copyright

Requested Five Times

\section{Subscription Price}

1. Consumers' Digest

2. Family Handyman

3. Electrical Construction and

Maintenance

4. Journal of Occupational Medicine

5. Journal of Political Economy

6. Nuclear Materials Management

7. Nursing Mirror and Midwives

Journal

8. Biomaterials, Medical Devices and Artificial Organs

9. Journal of Applied Meteorology

10. Geochemistry International

11. Toxicology and Applied

Pharmacology

$\frac{152.00}{\text { TOTAL COST }} \$ \$ 525.20$

Also included in this group was Consumer Reports, which the Library keeps for one year only.

Mean price $=\$ 47.75$

Median price $=\$ 20.00$

8.00

8.50

9.00

20.00

20.00

20.00

37.70

45.00

60.00

145.00 
TABLE 5 .

Foreign Journals Requested Five Times

Subscription Price

1. Minerva

2. Chemicke Zvesti

3. Architects' Journal
$\$ 14.00$

23.50

70.00

$\$ 107.50$

Mean price $=\$ 35.83$

Median price $=\$ 23.50$ 
BS.114A (REV. 7-73)

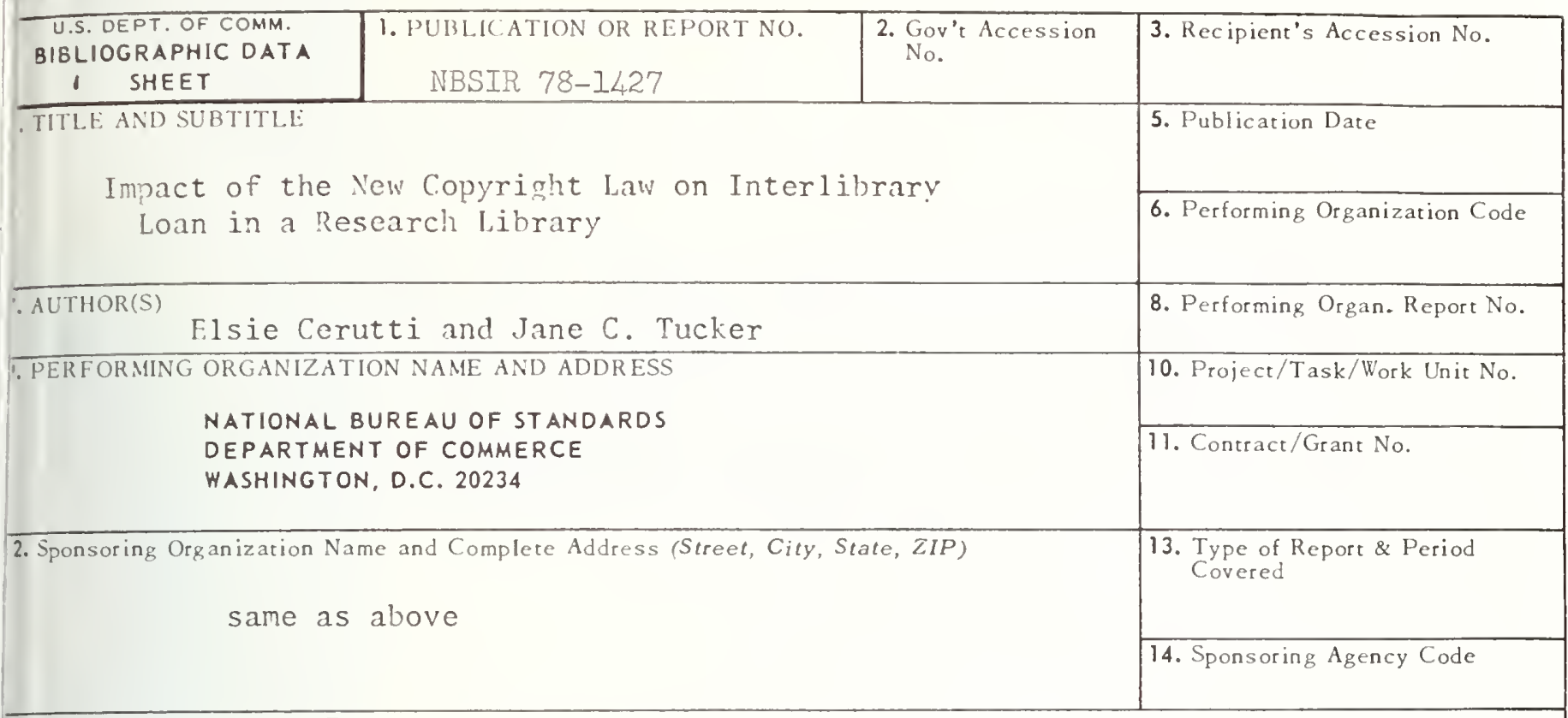

16. ABSTRACT (A 200-word or less factual summary of most significant information. If document includes a significant bibliography or literature survey, mention it here.)

A study of interlibrary loan borrowing at the Vational Bureau of Standards Library in 1976 was made, to forecast the impact of the new copyright law on the Library budget. The study indicates that the majority of journals are requested only once, and that a number of foreign journals are requested. An analysis of subscription cost compared to interlibrary loan cost suggests criteria for management decisions on subscription, as well as testing the fairness of the CONTU guidelines in their economic impact on libraries.

17. KEY WORDS (six to twelve entries; alphabetical order; capitalize only the first letter of the first key word unless a proper name; separated by semicolons)

Interlibrary loan; Copyright law; Periodical subseriptions; CONTU guidelines, Library eost-effectiveness analysis

\begin{tabular}{|c|c|c|}
\hline 18. AVAILABILITY $\quad \mathrm{x}]$ Unlimited & $\begin{array}{l}\text { 19. SECURITY CLASS } \\
\text { (THIS REPURT) }\end{array}$ & 21. NO. OF PAGES \\
\hline For Official Distribution. Do Not Release to NTIS & UNCL ASSIF IED & 19 \\
\hline $\begin{array}{l}\square \text { Order From Sup. of Doc., U.S. Government Printing Office } \\
\text { Washington, D.C. } 20402, \text { SD Cat. No. C13 }\end{array}$ & $\begin{array}{l}\text { 20. SECURITY CLASS } \\
\text { (THIS PAGE) }\end{array}$ & 22. Price \\
\hline $\begin{array}{l}\square \text { Order From National Technical Information Service (NTIS) } \\
\text { Springfield, Virginia } 22151\end{array}$ & UNCLASSIFIED & $\$ 4.00$ \\
\hline
\end{tabular}


